\title{
PREOPERATIVE SERUM LEVELS OF CA 72-4, CEA, CA 19-9, AND ALPHA-FETOPROTEIN IN PATIENTS WITH GASTRIC CANCER
}

Rejane Mattar, Claudio Roberto Alves de Andrade, Giovanni Mastrantonio DiFavero, Joaquim José Gama-Rodrigues and Antonio Atílio Laudanna

MATTAR R et al. - Preoperative serum levels of CA 72-4, CEA, CA 19-9, and Alpha-fetoprotein in patients with gastric cancer. Rev. Hosp. Clín. Fac. Med. S. Paulo 57(3): 2002.

INTRODUCTION: The clinical importance of preoperative serum levels of CA 72-4, carcinoembryonic antigen (CEA), CA 19-9, and alpha-fetoprotein (AFP) was prospectively evaluated in 44 patients with gastric cancer.

METHOD: The serum tumor marker levels were determined by commercial radioimmunoassay kits. Positivity for CA $72-$ $4(>4 \mathrm{U} / \mathrm{mL})$, CEA ( $>5 \mathrm{ng} / \mathrm{mL})$, CA 19-9 (>37 U/mL), and AFP (>10 ng/mL) were correlated according to the stage, histology, and lymph node metastasis.

RESULTS AND DISCUSSION: CA 72-4 showed a higher positivity rate for gastric cancer (47.7\%) than CEA (25\%), CA 19-9 (25\%), and AFP (0\%). The combination of CA 72-4 with CEA and CA 19-9 increased the sensitivity to 61.4\%. The positivity rates of CA 72-4 in patients at stages I and II (initial disease) and in patients at stages III and IV (advanced disease) were $9 \%$ and 60.6\%, respectively $(P<0.005)$. No correlation was found between CEA and CA 19-9 levels and the stage of gastric cancer. There was a tendency of positivity for CA 72-4 to suggest lymph node involvement, but it was not significant $(P=0.075)$. Serum levels of tumor markers did not show a correlation with the histological types of gastric cancer.

CONCLUSION: Preoperative serum levels of CA 72-4 provided a predictive value in indicating advanced gastric cancer.

DESCRIPTORS: Gastric cancer. CEA. CA 72-4. CA 19-9. Alpha-fetoprotein.

The high mortality rate from gastric cancer arises from its late detection and surgical resection at advanced stages of the disease ${ }^{1}$. However, particularly in Japan, mass screening for gastric cancer performed by endoscopy and double-contrast barium X-ray has contributed to early diagnosis and reduction of mortality from gastric cancer².

In 1969, Thomson et al. ${ }^{3}$ successfully demonstrated circulating carcinoembryonic antigen (CEA) in the sera of patients with large bowel cancer. This finding led the way to a new field of interest in tumor-associated antigens that could be useful for the early detection of cancer.
With the advent of monoclonal antibodies ${ }^{4}$, other tumor markers with special application for gastrointestinal tract malignancies were described. For adenocarcinoma of the pancreas, CA 19-9 is more specific and sensitive than CEA, the most widely used tumor marker $^{5,6}$. For gastric cancer, CA 72-4 was the marker that showed the higher sensitivity ${ }^{7}$. Nonetheless, due to their low sensitivity and specificity in detecting early primary tumor, tumor markers have shown little benefit as a method

From the Department of Gastroenterology, Hospital das Clínicas, Faculty of Medicine, University of São Paulo. for screening in the general population.

Tumor markers can be used clinically for the monitoring of tumor recurrence and used as prognostic factors because higher levels have been observed in advanced disease $e^{8-10}$. The combined assay of preoperative serum levels of CEA, CA 19-9, and CA 72-4 has provided additional prognostic information for patients resected for gastric cancer; patients with preoperative positivity for one of these possible tumor markers have a high risk of recurrence, even in the early stages of gastric cancer ${ }^{10}$.

The serum level of AFP (alphafetoprotein) has been widely used for 
hepatocellular carcinoma screening in patients with chronic liver disease $\mathrm{e}^{11-13}$. In recent years, many cases of AFPproducing gastric cancer, characterized by increased AFP serum levels and AFP positivity of the gastric cancer tissues, have been reported ${ }^{14}$. Alphafetoprotein-producing gastric cancer has been associated with a poor prognosis because of its high proliferative activity, weak apoptosis, and rich neovascularization, compared to that of AFP-negative gastric cancers. These biological characteristics of AFP-producing gastric cancer reflect the aggressive behavior of the tumor and the poor prognosis of patients with this type of cancer $^{15}$.

The purpose of our study was to determine which marker or combination of markers among CA 72-4, CEA, CA 19-9, and AFP would be the most useful for detecting gastric cancer.

\section{MATERIAL AND METHODS}

\section{Patients}

Forty-four patients with gastric cancer were selected for the study. The average age of patients (27 men, 17 women) was $64.3 \pm 10.9$ years. The tumors were classified as intestinal and diffuse types, according to Láuren ${ }^{16} ; 18$ patients had the diffuse type and 26 patients had the intestinal type. The TNM staging was performed according to the criteria of the Japanese Classification of Gastric Cancer ${ }^{17} ; 4$ patients had stage Ia cancer, 3 patients had stage Ib, 4 patients stage II, 5 patients stage IIIa, 13 patients stage IIIb, 8 patients stage IVa, and 7 patients stage I.

\section{Serum Markers}

Quantitative determinations of CA 72-4, CEA, CA 19-9, and AFP were performed using commercial radioimmunoassay kits (CIS Bio International, France). The cut-off values were $5 \mathrm{ng}$ / $\mathrm{mL}$ for CEA, $37 \mathrm{U} / \mathrm{mL}$ for CA 19-9, $4 \mathrm{U} /$ $\mathrm{mL}$ for $\mathrm{CA} 72-4$, and $10 \mathrm{ng} / \mathrm{mL}$ for AFP.
A result was considered positive when the marker serum level was higher than the cut-off value.

\section{Statistics}

The serum level of these tumor markers was investigated with respect to stage (initial or advanced disease), regional lymph node metastasis, and histology (intestinal or diffuse types) using the chi-square or Fisher exact test. Gender and age of the patients were correlated with the stage of the disease, regional lymph node metastasis, and histology using the chi-square or Fisher exact test.

\section{RESULTS}

Preoperative serum levels of CA 724, CA 19-9, CEA, and AFP were assayed in 44 patients with gastric cancer. Since none of the patients were positive for AFP, the analysis of AFP was excluded. CA 72-4 was positive in $21(47.7 \%)$ patients, CEA in $11(25 \%)$ patients, and CA $19-9$ in 11 (25\%) patients. The sensitivity of the combination of CA 72-4 and/ or CA $19-9$ was $56.8 \%$; of CA 72-4 and/or CEA was $54.5 \%$, and of CEA and/ or CA $19-9$ was $43.2 \%$. The three markers together showed a sensitivity of $61.4 \%$.

CA 72-4 was positive in $9 \%$ of patients at stages I and II (initial disease) and in $60.6 \%$ of patients at stages III and IV (advanced disease), as shown in table 1 . This difference was signifi-

Table 1- Positive rate of CA 72-4, carcinoembryonic antigen (CEA) and CA19-9 in gastric cancer patients grouped according to initial and advanced disease, lymphatic invasion and histology.

\begin{tabular}{lccc}
\hline Gastric cancer & CA 72-4 & $\begin{array}{c}\text { Carcinoembryonic } \\
\text { antigen (CEA) }\end{array}$ & CA 19-9 \\
\hline Initial (stages I/II) $\mathrm{n}=11$ & $1(9 \%)$ & $1(9 \%)$ & $2(18.2 \%)$ \\
Advanced (stages III/IV) $\mathrm{n}=33$ & $20(60.6 \%) *$ & $10(30.3 \%)$ & $9(27.3 \%)$ \\
Lymph node invasion (-) $\mathrm{n}=12$ & $2(16.7 \%)$ & $2(16.7 \%)$ & $2(16.7 \%)$ \\
Lymph node invasion (+) $\mathrm{n}=22$ & $11(50 \%)$ & $5(22.7 \%)$ & $3(13.6 \%)$ \\
Diffuse type $\mathrm{n}=18$ & $10(55.6 \%)$ & $5(27.8 \%)$ & $4(22.2 \%)$ \\
Intestinal type $\mathrm{n}=26$ & $11(42.3 \%)$ & $6(23.1 \%)$ & $7(26.9 \%)$ \\
\hline
\end{tabular}

$* \mathrm{p}<0.005$ for CA $72-4$ cant $(P<0.005)$ when assessed by the chi-square test. CEA was positive in $9 \%$ of patients with initial disease and in $30 \%$ of patients with advanced disease $(P>0.05)$. CA 19-9 was positive in $18.2 \%$ of patients with initial disease and in $27.3 \%$ of patients with advanced disease $(P>0.05)$.

Regarding the lymph node status of the patients, 12 had no lymphatic invasion and 22 had regional lymph node metastasis (Table 1). Ten patients who had advanced disease did not undergo surgery; thus, they were excluded from this analysis. CA 72-4 was positive in $11(50 \%)$ patients with lymph node metastasis and in $2(16.7 \%)$ patients negative for lymphatic invasion $(P=0.075)$. CEA was positive in $5(22.7 \%)$ patients with lymph node metastasis and in 2 (16.7\%) patients negative for lymphatic invasion $(P>0.05)$. CA $19-9$ was positive in $3(13.7 \%)$ patients with lymph node metastasis and in $2(16.7 \%)$ patients negative for lymphatic invasion $(P>0.05)$.

There was no correlation of the positivity rate of CEA, CA 72-4, and CA 199 with the histological types (Table 1). There was also no correlation of sex and age to histology, early and advanced disease, and lymph node invasion (data not shown).

\section{DISCUSSION}

The use of tumor markers has become a very attractive method for the detection and diagnosis of neoplastic 
diseases, as well as for the monitoring of their course after radical surgery or during chemotherapy ${ }^{18,19}$. One of the challenging problems in the diagnosis and postoperative follow-up of patients with gastric cancer is the low sensitivity of the tumor markers that are currently being used ${ }^{8}$.

Since the role of tumor markers in gastric cancer is still controversial, we prospectively studied the serum levels of CA 72-4, CEA, CA 19-9, and AFP in patients with gastric cancer who were being evaluated for surgery. Previous studies of serum levels of CEA, CA 199, and CA 72-4 in gastric cancer have demonstrated that the positivity of these markers has a wide range of variation, from $14 \%$ to $42 \%$ for $\mathrm{CEA}^{1-8,10,20-22}$, from $16 \%$ to $38.4 \%$ for CA $19-9^{7,8,10,21,22}$, and from $24.2 \%$ to $45.3 \%$ for CA 72-47,9,10,22.

According to our results, CA 72-4 alone presented an even higher positivity rate $(47.7 \%)$ than the combination of CEA and CA 19-9 (43.2\%). The best combination of tumor markers was $\mathrm{CA}$ 72-4 and CA 19-9 (56.8\%), which was similar to that of a previous report ${ }^{23}$. None of the patients were positive for AFP; the positivity of AFP in gastric cancer has been reported to be low $(15 \%)^{24}$, and usually, AFP has been a marker of aggressive behavior tumor and poor prognosis ${ }^{15}$.

When the patients with gastric cancer were divided into 2 groups, initial (stage I/II) and advanced disease (stage III/IV), CA 72-4 was the best marker $(60.6 \%)$ for advanced disease $(P$ $<0.005)$. Serum levels of CEA and CA 19-9 exhibited no significant differences between cases of initial and advanced disease. The superiority of CA 72-4 for gastric cancer over CEA and CA 19-9 has been previously demonstrated by other authors ${ }^{7,22,23}$. However, CA 72-4 seems to be a marker of advanced disease, rather than a marker for mass survey screening for the detection of early disease. After curative surgery, CA 724 could be used to monitor recurrence or metastasis in those cases that had elevated serum levels prior to surgery.

There was a tendency for CA 72-4 to also be a marker for lymph node involvement; nonetheless, it was not significant $(P=0.075)$. The discrimination of the lymph node status of the patients could have clinical applications for staging. CEA, CA 72-4, and CA 19-9 were considered markers of lymph node involvement in other reports $^{8,10,20}$. Ikeguchi et al ${ }^{9}$ found that CEA was a good indicator of lymph node metastasis, while CA 72-4 was a good predictor of peritoneal metastasis. In our study however, CEA and CA 19-9 were neither indicators of lymph node involvement nor of advanced disease.

Serum levels of tumor markers showed no correlation to the histology of the tumor. Some authors have tried to explain the low sensitivity of tumor markers in their studies in terms of the histology of the tumor, with the diffuse type of gastric cancer presenting the lowest positivity rate of the markers ${ }^{21}$. However, this correlation is still controversial, since in other reports, the positivity rate of CEA, CA 72-4, and CA 19-9 was higher in the diffuse type ${ }^{7}$. Nonetheless, other authors have also shown no correlation between tumor marker levels and the histology of gastric cancer ${ }^{10}$.

The ease of blood sampling makes serologic tumor marker tests very attractive for the detection of neoplastic diseases. The search for more sensitive methods, along with more specific and sensitive tumor markers for gastric cancer, is still under way. A novel sensitive method, which has been termed immuno-polymerase chain reaction (immuno-PCR), was developed for the detection of gastric carcinoma-associated antigen MG7Ag. The comparison of immuno-PCR and commercial assays for tumor markers demonstrated that the sensitivity of immuno-PCR was $81.4 \% 22$.

In conclusion, the results of the current study showed that CA 72-4 was the best marker for advanced gastric cancer; nevertheless, in the future, more sensitive techniques using other tumor-associated antigens should be developed.
MATTAR R e col.- Níveis séricos préoperatórios de CA 72-4, CEA, CA 199 e Alfa-fetoproteína em pacientes com câncer gástrico. Rev. Hosp. Clín. Fac. Med. S. Paulo 57(3): 2002.

INTRODUÇÃO: A importância clínica dos níveis séricos pré-operatórios de CA 72-4, antígeno carcinoembrionário (CEA), CA 19-9 e alfa-fetoproteína (AFP) foi avaliada prospectivamente em 44 pacientes com câncer gástrico.

MÉTODOS: Os marcadores tumorais foram quantificados com o emprego de kits comerciais de radioimunoensaio. A positividade dos marcadores, CA 72-4 (>4 $\mathrm{U} / \mathrm{ml}), \mathrm{CEA}(>5 \mathrm{ng} / \mathrm{ml}), \mathrm{CA} 19-9$ (>37 U/ $\mathrm{ml})$ e AFP (>10 ng/ml), foi correlacionada com o estágio da doença, a histologia do tumor e comprometimento de linfonodo.

\section{RESULTADOS E DISCUSSÃO: O} marcador CA 72-4 apresentou maior positividade para o câncer gástrico $(47,7 \%)$ que CEA (25\%), CA 19-9 (25\%) e AFP $(0 \%)$. A associação de CA 72-4, CEA e CA 19-9 aumentou a sensibilidade para $61,4 \%$. A positividade do CA 72-4 nos pacientes com estágios I e II (Doença Inicial) e nos pacientes com estágios III e IV 
(Doença Avançada) foi de 9 e $60,6 \%$, respectivamente $(\mathrm{p}<0,005)$. Não foi observada correlação entre os níveis séricos de CEA e CA 19-9 com o estágio do câncer gástrico. O CA 72-4 apresentou tendência de sugerir comprometimento de linfonodo, mas não foi significativo $(\mathrm{p}=0,075)$. Não houve correlação entre os níveis séricos dos marcadores tumorais com os tipos histológicos de câncer gástrico.
CONCLUSÃO: A positividade do CA 72-4 teria o valor de indicar os casos de câncer gástrico avançadono pré-operatório.

DESCRITORES : Câncer gástrico. CA 72-4. CEA. CA 19-9. Alfa-fetoproteína.

\section{REFERENCES}

1.DOGLIETO GB, PACELLI F, CAPRINO P et al. - Surgery: independent prognostic factor in curable and far advanced gastric cancer. World J Surg 2000; 24:459-463.

2.KUBOTA H, KOTOHT, MASUNAGA R et al. - Impact of screening survey of gastric cancer on clinicopathological features and survival: retrospective study at a single institution. Surgery $2000 ; \mathbf{1 2 8}: 41-47$.

3.THOMSON DMP, KRUPEY J, FREEDMAN SO et al. - The radioimmunoassay of circulating carcinoembryonic antigen of the human digestive system. Proc Natl Acad Sci (USA) 1969; 64:161-167.

4.KOHLER G \& MILSTEIN C - Continuous cultures of fused cells secreting antibody pre-defined specificity. Nature $1975 ; 256$ : 495-499.

5.PEZZILLI R, BILLI P, PLATE L et al. - Serum CA 242 in pancreatic cancer. Comparison with CA 19-9 and CEA. Int J Gastroenterol 1995; 27:296-299.

6.NAZLI O, BOZDAG AD, TANSUG $\mathrm{T}$ et al. - The diagnostic importance of CEA and CA 19-9 for the early diagnosis of pancreatic carcinoma. Hepatogastroenterology 2000; 47: $1750-1752$.

7.KODAMA I, KOUFUJI K, KAWABATA $S$ et al. - The clinical efficacy of CA 72-4 as a serum marker for gastric cancer in comparison with CA 19-9 and CEA. Int Surg 1995; 80:4548.

8.KODERA Y, YAMAMURA Y, TORII A et al. - The prognostic value of preoperative serum levels of CEA and CA 19-9 in patients with gastric cancer. Am J Gastroenterol 1996; 91: 49-53.

9.IKEGUCHI M, KATANO K, SAIT OU H et al. - Pre-operative serum levels of CA 72-4 in patients with gastric adenocarcinoma. Hepato-Gastroenterology $1997 ; 4$ 44:866-871.

10.MARRELLI D, ROVIELLO F, DE STEFANO A et al. - Prognostic Significance of CEA, CA 19-9 and CA 72-4 preoperative serum levels in gastric carcinoma. Oncology 1999; 57:55-62.

11.CEDRONE A, COVINO M, CATURELLI E et al. - Utility of alpha-fetoprotein (AFP) in the screening of patients with virus-related chronic liver disease: does different viral etiology influence AFP levels in HCC? A study in 350 western patients. Hepatogastroenterology 2000; 47:1654-1658.

12.PENG YC, CHAN CS \& CHEN GH - The effectiveness of serum alpha-fetoprotein level in anti-HCV positive patients for screening hepatocellular carcinoma. Hepatogastroenterology 1999; 46:3208-3211.
13. BAYATI N, SILVERMAN AL \& GORDON SC - Serum alphafetoprotein levels and liver histology in patients with chronic hepatitis C. Am J Gastroenterol 1998; 93:2452-2456.

14. HYODO T \& KAWAMOTO R - Double cancer of the stomach, one AFP-producing tumor. J Gastroentrol 1996; 31:851854.

15. KOIDE N, NISHIO A, IGARASHI J \& KAJIKAWA S - Alphafetoprotein-producing gastric cancer: histochemical analysis of cell proliferation, apoptosis, and angiogenesis. A m J Gastroenterol 1999; 94:1658-1663.

16. LAURÉN P - The two histological main types of gastric carcinoma: diffuse and so-called intestinal-type. Acta Pathol Microbiol Scand 1965; 64:31-49.

17. JAPANESE Research Society for Gastric Cancer. Japanese classification of gastric carcinoma. Tokyo, Kanehara, 1995.

18. YAMAO T, KAI S, KAZAMI A et al. - Tumor markers CEA, CA 19-9 and CA 125 in monitoring of response to systemic chemotherapy in patients with advanced gastric cancer. Jpn J Clin Oncol 1999; 29:550-555.

19. PECT ASIDES D, MYLONAKIS A, KOST OPOULOU $\mathrm{M}$ et al. CEA, CA 19-9, and CA-50 in monitoring gastric carcinoma. Am J Clin Oncol 1997; 20: 348-353.

20. HORIE Y, MIURA K, MATSUI K et al. - Marked elevation of plasma carcinoembryonic antigen and stomach carcinoma. Cancer 1996; 77: 1991-1997.

21. ISHIGAMI S, NATSUGOE S, HOKITA S et al. - Clinical importance of preoperative carcinoembryonic antigen and carbohydrate antigen 19-9 levels in gastric cancer. J Clin Gastroenterol 2001; 32:41-44.

22. REN J, CHEN Z, ZHOU SJ et al. - Detection of circulating gastric carcinoma-associated antigen MG7-Ag in human sera using an established single determinant immuno-polymerase chain reaction technique. Cancer 2000; 88:280-285.

23. GARTNER U, SCHEULEN ME, CONRADT C et al. - Value of tumor-associated antigens CA 72-4 vs. CEA and CA 19-9 in the follow-up after stomach cancer. Dtsch Med Wochenschr 1998; 123:69-73.

24. WEBB A, SCOTT-MACKIE P, CUNNINGHAM D et al. - The prognostic value of serum and immunohistochemical tumour markers in advanced gastric cancer. Eur J Cancer 1996; 32 A:63-68 